\title{
Dewey's Theory of Experience: A Theoretical Tool for Researching Music Teacher Learning
}

\author{
Jody Stark
}

University of Manitoba, Canada

This article explores Dewey's theory of experience and its potential as a theoretical tool to notice, and make sense of, music teacher learning. Beginning with the assumption that music teachers' capacity to grow professionally is integral for change in the field of music education, I present several illustrative examples of how Dewey's theory informed the interpretive work for a study of the professional learning of three elementary music teachers. While useful in many ways, a Dewey an framework proved to have certain limitations related to the socially constructed and discursive nature of learning and teaching elementary music. As a result, several concepts from Lave and Wenger's sociocultural theory and Bourdieu's practice theory were used in theorizing these aspects of teachers' experience and practice.

Keywords: Dewey, theory of experience, music teacher professional learning, professional growth, interpretive inquiry, collective case study, Lave and Wenger, Bourdieu

$J$

ohn Dewey (1859-1952) was a prolific writer who wrote extensively on education and the arts. As such, his work has proven to be a rich source of theoretical ideas for scholars in music education. While Dewey did not address music specifically, 2oth century music education philosophers such as Leonhard and House (1959/1972) and Reimer (1970/1983/2003) have used Dewey's ideas in their articulations of an aesthetic philosophy of music education. More recently, Allsup's (2016) “open philosophy” for music education has drawn inspiration from Deweyan philosophy along with Maxine Greene's and Roland Barthes' writings. Dewey has also featured in the work of many MayDay Group scholars. For example, Terry Gates' (1974) dissertation research explored the potential of Dewey's later writings, including Dewey's theory of experience, as the basis of a coherent philosophy of music education. More recently, Heidi Westerlund (2003) has used Dewey (1934/1980) to argue for the importance of aesthetic experience within a praxial framing of music education, while the implications of various Deweyan

(C) Jody Stark. The content of this article is the sole responsibility of the author. The ACT Journal and the Mayday Group are not liable for any legal actions that may arise involving the article's content, including, but not limited to, copyright infringement. 
concepts such as reflective thinking and the intentional creation of consummatory experiences have been examined for their relevance to the field of music education by Paul Woodford (1994) and Thomas Regelski (2017). Woodford (2018) has also invoked Dewey's writings on education and democracy in relation to the ethical, moral, and political implications of music education in a democratic society, and he has examined the ways that leaders in the field of music education have conveniently ignored Dewey's politics while borrowing from Dewey's aesthetic philosophy. This brief account of scholars in music education who have used Dewey in their work is admittedly incomplete, but it serves to make the point that Dewey has had considerable influence on the work of many in our field.

Along with these esteemed scholars, Dewey has had a significant impact on my thinking. As a Ph.D. student, I studied with narrative inquirer Jean Clandinin, who uses Dewey's theory of experience as a theoretical framework for inquiring narratively into teachers' and students' experiences. After my experience in Jean's class and reading Dewey in a curriculum studies course, Dewey firmly had my attention, so much so that I used his theory of experience to frame my Ph.D. study of music teacher professional learning. In the present, I often think about Dewey's theory of experience as I teach future music educators, and I frequently turn to Dewey as I ponder the why and how of music education. Dewey's theory has been significant and useful for me in thinking about teaching and learning. Dewey has become part of my experience.

In this article, I discuss Dewey's theory of experience and argue for its potential as a theoretical tool to notice, and make sense of, music teacher learning. First, I make the case that a more nuanced understanding of how music teachers learn is critical to enacting and supporting change in the field of music education. I then provide a brief overview of my framing of Dewey's theory of experience before sharing several illustrative examples of how Dewey's theory informed my interpretive work in the collective case study of elementary music teachers' professional learning I undertook for my dissertation research. I then close with a reflection on the ways that I have found Dewey's theory to be useful in deepening my understanding of teacher professional learning, while also exploring the limitations of this theoretical frame.

Jody Stark. 2020. Dewey's theory of experience: A theoretical tool for researching music teacher learning. Action, Criticism, and Theory for Music Education 19 (1): 118-52. https://doi.org/ 10.22176/act19.1.118 


\section{Why Music Teacher Learning Matters}

While there is no question that philosophy, curriculum, policy, and theory are important in guiding change for music teaching and learning, lasting and meaningful change also depends to a large degree on the actions of music teachers in their classrooms. Bautista, Yau, and Wong (2017) argue that teachers are "crucial to the success of educational reforms," as they are ultimately the ones who enact change at the classroom level (455). But changing one's teaching practice is a highly complex endeavor rooted in teachers' subjectivity. Such changes are ultimately the result of one's professional learning, and professional learning is a situated and interactive process that occurs over an extended period of time (Stark 2020). Teachers learn informally from their students, colleagues, administrators, and school community (Bush 2007, Conway 2008), as well as through participation in formal professional learning events such as workshops and courses (Barrett 2006, Shaw 2017, Williamson 2011), conferences (Burkett 2011) and by taking part in music ensembles and individual music lessons (Pellegrino 2011). They refine their practice through engaging in inquiry projects and action research (West 2011), participating in professional development communities and collaborative teacher study groups (Dorfman and Lipscomb 2005, Kastner 2014, Sindberg 2016, Stanley 2009), mentoring teacher candidates and novice teachers (Raschdorf, 2015), taking masters-level classes (Barrett 2009; Conway, Eros, and Stanley 2009; Kos and Goodrich 2012), and taking on leadership in community organizations (Barrett 2006). Their growth as professional learners is complex and multifaceted (Opfer and Pedder 2011) and is informed by their beliefs about teaching and learning (Butler 2001; de Vries, Jansen, and van de Grift 2011). The result of teachers' professional learning is what constitutes professional growth, and professional growth relies on, and results in, changes in practice (Stark 2020). In the following section, I articulate my framing of Dewey's theory of experience and argue for its potential as a theoretical tool for studying music teacher professional learning.

\section{Dewey and the Nature of Experience}

A central idea in Dewey's work is experience. Dewey saw experience as "things interacting in certain ways" $(1925 / 2015,4 a)$. As such, experience is the "irreducible totality of people acting, sensing, thinking, feeling, and meaning-making in a setting” (Wright, McCarthy, and Meekison 2005, 44). Significantly, Dewey allows for

Jody Stark. 2020. Dewey's theory of experience: A theoretical tool for researching music teacher learning. Action, Criticism, and Theory for Music Education 19 (1): 118-52. https://doi.org/ 10.22176/act19.1.118 
no duality between the person doing the experiencing and the world in which they are situated. Instead, he sees the concept of experience as being "'double barreled' in that it recognizes in its primary integrity no division between act and material, subject and object, but contains them both in an unanalyzed totality" (Dewey 1925/2015, 10).

But not all experiences are equal. Dewey makes the distinction between (1) "experiencing," and (2) "an experience." He cautions, "oftentimes ... the experience had is inchoate. Things are experienced but not in such a way that they are composed into an experience" (1934/1980, 35). Thus, experiencing is merely being present when something happens (e.g., I go on a fieldtrip with my Grade 2 class to the zoo and pet a giraffe). In contract, an experience has unity and continuity inherent in its structure. An experience results from an intentional action where "the material experienced runs its course to fulfillment" (35) (e.g., I participate in an experiment in science class and then reflect on what I observed). Whereas experiencing simply ceases, an experience is marked by consummation. A consummatory experience for Dewey is a "good" and fulfilling experience, where, in Westerlund's (2003) words, "in the immediacy of the present moment ... one's prior efforts are brought to fruition" (54). Such an experience results in growth. But how is consummation related to learning? Simply put, a consummatory experience is characterized by "a unified heightened sense of meaning leading to truly educative experience" (Oral 2012, 166-7). The notion of an educative experience leads me to Dewey's (1938/1997) theory of experience.

\section{Dewey's Theory of Experience}

Dewey's pragmatic theory of experience represents the philosopher's attempt to explicate the process through which human beings learn and grow. While Dewey's ideas on experience, learning, and the relationship between the two can be traced through much of his work to varying degrees, I will draw especially from two of Dewey's later works, namely, Experience and Education (1938/1997) and Experience and Nature (1925/2018). In the first, Dewey suggests that growth, which is Dewey's metaphor for learning, is intimately tied to experience, although the two terms are by no means synonymous. One, experience, is the vehicle for the other. Wojcikiewicz (2010) points out that Dewey has a particular kind of experience in mind when he talks about the potential for experience to engender learning. An

Jody Stark. 2020. Dewey's theory of experience: A theoretical tool for researching music teacher learning. Action, Criticism, and Theory for Music Education 19 (1): 118-52. https://doi.org/ 10.22176/act19.1.118 
educative experience is one that does not "narrow the field of future growth" (Dewey 1938/1997, 26) and instead enhances the potential for further learning and development. The kind of experience Dewey has in mind is not mere activity (i.e., not just experiencing), but "doing something with a certain awareness of what one is about" (Wojcikiewicz 2010, 67); an experience always has an element of intention.

In brief, Dewey argues that in order for an experience to result in growth (i.e., for it to be an educative experience), it has to meet the dual criteria of continuity and of interaction. An experience is also situated in a particular time and place. In sum, experience resulting in growth depends on (1) the relationship between a current experience and past and future ones, (2) both the material and social context of a person's situation, and (3) an individual's interactions within the learning situation/environment. I will briefly discuss all three of these dimensions of Dewey's theory.

\section{Criteria of Continuity}

Dewey argues that an educative experience is temporally located on an "experiential continuum" (1938/1997, 33). A person's current experience is thus shaped by their previous experience, and their current experience impacts their future experience: "Every experience both takes up something from those which have gone before and modifies in some way the quality of those which come after" (Dewey 1938/1997, 35). As Garrison (1994) points out, learning therefore has ontological consequences. The learner literally becomes someone else through their experience, which, in turn, impacts their possible future and who they are in the present. Growth therefore relies on the "principle of continuity" (36), whereby new experiences literally change the person, which in turn changes all subsequent experiences.

\section{Situation}

In addition to the temporal criteria of continuity, all experiences are shaped by a person's situation. Because the human condition is not just to live, but to live in the world, Dewey notes that our experience is located "in a series of situations" (1938/1997, 43). Westerlund (2003) points out that Dewey's philosophy is

Jody Stark. 2020. Dewey's theory of experience: A theoretical tool for researching music teacher learning. Action, Criticism, and Theory for Music Education 19 (1): 118-52. https://doi.org/ 10.22176/act19.1.118 
inherently anti-foundationalist and therefore does not allow for dualism of any kind. Brodsky (1964), quoting Dewey, concurs. Brodsky writes, "the term 'situation' is introduced by Dewey to mark the fact that this union of [hu]man and nature is "prior to, neutral to, and inclusive of, any distinction and relation that can be legitimately instituted between subject and object."' As mentioned above, Dewey strongly rejects a separation of the person and their environment. Dewey writes, "Experience does not go on simply inside a person ... [and it] does not happen in a vacuum. There are sources outside of a person which give rise to experience" (1938/1997, 39-40). Experience is always located in a particular moment and place in the world that influences the experience, and the person having the experience is part of that world. Another way of saying this is that experience is situated. A person's situation consists of "whatever conditions interact with personal needs, desires, purposes, and capacities to create the experience which is had" $(1938 / 1997,44)$. A Deweyan understanding of music teacher professional learning sees teacher learning as specific to a particular situation where the teacher is an important part of their context through the process of interaction.

\section{Criteria of Interaction}

Just as a teacher's situation influences their experience, the teacher influences their situation. Situation, therefore, is inseparable from the notion of interaction, and interaction is Dewey's second criterion of an educative experience. Dewey sees experience as being shaped in the dialectic interaction between the "objective and internal conditions" of the person and their context $(1938 / 1997,42)$. This interplay between the person's subjectivity and their environment is transactional in nature. Dewey writes, "An experience is always what it is because of the transaction taking place between the individual and what, at the time, constitutes his [or her] environment" $(1938 / 1997,43)$. This is Dewey's non-dualist dialectic in action: People interact with the social and physical world around them in a continual process of mutual adaptation. While Dewey labels this criterion of experience "interaction," Bredo (1997) reminds us that the character of what Dewey is envisioning is transactional in nature. Bredo (1997) writes, "Dewey's theory was transactional not interactional, in that it allowed for changes in the character of both organism and environment" (15). Rather than being a linear relationship between a person and their situation, Dewey is suggesting that "organisms are engaged in 'trying' and

Jody Stark. 2020. Dewey's theory of experience: A theoretical tool for researching music teacher learning. Action, Criticism, and Theory for Music Education 19 (1): 118-52. https://doi.org/ 10.22176/act19.1.118 
'undergoing,' in which the environment is modified and modifies the actor, in turn, in a cycle, until some result is achieved" (Bredo 1997, 10). ${ }^{1}$

Together, interaction/transaction, continuity, and situation create the conditions for the kind of experience likely to facilitate learning and growth. A central thesis of this article is therefore this: Because interaction, continuity, and situation are aspects of experiences that have the potential to result in meaningful learning, attending to these three aspects may be useful for theorizing music teacher professional learning and making sense of how teachers grow professionally. Understanding the "how" of music teachers' professional learning is critical to facilitating change in music education. In the next section, I will briefly describe my Ph.D. study and then provide several examples of the ways that the concepts of interaction, continuity, and situation were useful in my interpretive work.

\section{A Study of Music Teacher Professional Learning}

Situating the Research

From the early days of my teaching career when I was involved in organizing workshops for a community music association, I have always been deeply interested in music teachers' ongoing learning. In fact, I can point to several significant experiences that have helped me to define and hone that interest. I will briefly mention two. Around 10 years ago, I met an early career teacher who took a graduate course I was teaching for in-service elementary music educators. "Violet" was a committed and dynamic educator who was highly organized and open to trying new things. After the course ended, she asked me if I would help her create her year plans for the following year. As we worked, I realized that Violet's practice had not moved in the direction I had hoped it would change. Several of the key ideas around which I had designed the course were not apparent in her thinking. This stark (and humbling) realization caused me to wonder what it takes to influence teachers' thinking and teaching practice. I reflected on my own decade-long journey to embody a learner-centered and socially just approach to teaching only to occasionally find myself standing at the front of the class lecturing. Violet helped me to realize that changing one's teaching practice is a slow and complex process.

A second key experience occurred at the beginning of my doctoral journey during a research interview with a fellow music educator I shall call Ivy. In spite of the

Jody Stark. 2020. Dewey's theory of experience: A theoretical tool for researching music teacher learning. Action, Criticism, and Theory for Music Education 19 (1): 118-52. https://doi.org/ 10.22176/act19.1.118 
assumptions I had brought to our conversation about music teacher learning, Ivy helped me to see that the most significant element shaping her practice was not how she had been taught to teach music, but was instead her sense of identity and belonging in a specific community of practice. Through this experience with Ivy, I began to see that teacher education and professional learning, in order to be meaningful, must address not only the nuts and bolts of practice, but also the elements that undergird and surround practice: Epistemology, beliefs, identity, voice, context, belonging, and community. In short, teacher learning is complex, multifaceted and influenced by social interactions because teachers are complex, multifaceted, and located in specific communities.

While scholars have come to a consensus on characteristics and potential models of meaningful teacher professional development (Barrett 2006; Bauer 2007, 2012; Bautista, Yau, and Wong 2017; Bush 2007; Conway 2007, 2008; Conway, Christensen, Garlock, Hansen, Reese, and Zerman 2012; Conway, Hibbard, Albert, and Hourigan 2005; Poekert 2012; Robbins and Schmidt 2011; Stanley 2009, 2011, 2012; Stanley, Snell, and Edgar 2013; Thiessen and Barrett 2002; Wells 2013; Williamson 2011; Young 2013), Borko (2004) notes that little is known about how teachers actually learn from their professional learning experiences. She suggests that professional learning events are often conflated with teacher learning, both in scholarship and in practice. Because my interest was to understand how music teachers learned and managed to "forge a sustainable path for growth" throughout their careers (Barrett 2006, 26), I turned to Dewey.

\section{Purpose and Methodology}

The purpose of my dissertation study was to develop a more nuanced understanding of how three music teachers experienced their work and their professional learning. I sought to better understand the preoccupations, beliefs, and actions that shaped the three participants' practice and learning (Doyle 2012, Odena and Welch 2007), and how their environment impacted their thinking and work. I wondered how elementary music teachers continued to learn about teaching music as they experimented in their classrooms, attended formal professional learning events, and interacted with colleagues and peers. My assumption was that a better understanding of how the participants learned would help me to support other music teachers in engaging in professional learning that would lead to growth and

Jody Stark. 2020. Dewey's theory of experience: A theoretical tool for researching music teacher learning. Action, Criticism, and Theory for Music Education 19 (1): 118-52. https://doi.org/ 10.22176/act19.1.118 
changes in practice. Along with the assumption that teachers' professional growth is impacted by continuity, situation, and interaction, I worked from the belief that teaching and learning are inseparable elements of teachers' practice. Wenger (1998) writes that, "learning is the engine of practice and practice is the history of that learning" (97). Together, learning and teaching constitute and embody teachers' history, knowledge, beliefs, and actions.

The two research questions to which I specifically sought to respond were:

1. How do the participants experience their work as elementary music teachers?

2. How do the participants engage in professional learning?

I chose interpretive case study methodology (Patterson and Williams, 2002) because I wanted to better understand the process of professional learning and how teachers' real-life contexts influenced their experiences of professional learning. According to Merriam (1998), both are facilitated by case study research. I chose a collective case study design in order that I might develop a more nuanced understanding of the phenomenon of music teacher professional learning within and across settings (Baxter and Jack 2008).

Each of the cases of my study consisted of one elementary music teacher working for the same large school division in Alberta, Canada. "Gabriel," "Holly," and "Deborah" had all attended the same university (at different times) for their preservice teacher education. While Gabriel was able to count his participation in OrffSchulwerk level 1 towards his Bachelor of Education degree, neither Holly nor Deborah had taken coursework intended for music specialists as part of their B. Ed. experience. ${ }^{2}$ All of the participants had completed Orff-Schulwerk levels 1 and 2, and Holly had also completed Kodály levels 1 and 2 and had also returned to university after working as a Grade 1 classroom teacher for several years to do a specialist certificate program in music education. Holly was the only participant who attended a workshop during the period of the study, although all three participants were engaged in professional learning related to their teaching. The following table provides a summary of the three cases:

Jody Stark. 2020. Dewey's theory of experience: A theoretical tool for researching music teacher learning. Action, Criticism, and Theory for Music Education 19 (1): 118-52. https://doi.org/ 10.22176/act19.1.118 


\begin{tabular}{|l|l|l|l|l|}
\hline $\begin{array}{l}\text { Pseudo- } \\
\text { nym }\end{array}$ & Career Stage & Background & $\begin{array}{l}\text { Teaching } \\
\text { Assignment }\end{array}$ & Notes \\
\hline Gabriel & $\begin{array}{l}\text { First-year } \\
\text { teacher (also } \\
\text { taught private } \\
\text { studio and } \\
\text { group cello } \\
\text { lessons) }\end{array}$ & $\begin{array}{l}\text { B. Mus. and B. } \\
\text { Ed. After De- } \\
\text { gree3 } \\
\text { Had completed } \\
\text { Orff level 1 and 2 }\end{array}$ & $\begin{array}{l}\text { Low socio- } \\
\text { economic status, } \\
\text { highly transient } \\
\text { population }\end{array}$ & $\begin{array}{l}\text { Saw himself as a } \\
\text { string player and } \\
\text { a music educator }\end{array}$ \\
\hline Holly & $\begin{array}{l}\text { Mid-career } \\
\text { teacher in 11th } \\
\text { year of teach- } \\
\text { ing } \\
\text { (also taught } \\
\text { studio piano } \\
\text { and voice) }\end{array}$ & $\begin{array}{l}\text { B. Ed. and 1-year } \\
\text { music education } \\
\text { diploma; had } \\
\text { also completed } \\
\text { Orff and Kodály } \\
\text { level 1 and 2 }\end{array}$ & $\begin{array}{l}\text { Middle class, } \\
\text { ethnically di- } \\
\text { verse school pop- } \\
\text { ulation }\end{array}$ & $\begin{array}{l}\text { First year in a } \\
\text { new school in a } \\
\text { new district }\end{array}$ \\
\hline $\begin{array}{l}\text { Deborah } \\
\text { teacher in 29th } \\
\text { year of teach- } \\
\text { ing }\end{array}$ & $\begin{array}{l}\text { B. Ed. and M. } \\
\text { Ed. } \text { Had also taught } \\
\text { elementary } \\
\text { home room } \\
\text { Had completed } \\
\text { Orff level 1 and 2 }\end{array}$ & $\begin{array}{l}\text { Middle to upper } \\
\text { middle class } \\
\text { population with } \\
\text { English and } \\
\text { French } \\
\text { Immersion } \\
\text { program streams }\end{array}$ & $\begin{array}{l}\text { Had a keen } \\
\text { interest in } \\
\text { assessment; } \\
\text { Involved in a } \\
\text { collaborative } \\
\text { learning project } \\
\text { with a colleague }\end{array}$ \\
\hline
\end{tabular}

Table 1: Summary of Participants in Study

Data were collected over a period of five months and consisted of transcripts from an initial 60 to 75 -minute semi-structured interview and four to five short conversational interviews with each participant, as well as field notes from two classroom observations of each teacher in their respective schools. I also constructed field notes from one studio observation of Holly because she had invited me to observe her teaching piano lessons in her studio. The field notes from this observation were useful for part/whole hermeneutic analysis related to my first research question. Additionally, I collected artifacts that were provided by each participant in response to one or two Pre-Interview Activity (PIA) prompts. These were shared by the participant at their first interview. PIAs are a hermeneutic data collection activity designed to facilitate recall and reflection, which also help to clarify participants' preoccupations (Ellis 2006). They are intentionally designed to give the participant choices in what to share, and prompts relate either to the phenomenon being researched or the participant's life and experience (Ellis, Janjic-Watrich, Macris, and Marynowski 2011).

Jody Stark. 2020. Dewey's theory of experience: A theoretical tool for researching music teacher learning. Action, Criticism, and Theory for Music Education 19 (1): 118-52. https://doi.org/ 10.22176/act19.1.118 
As I collected data, I also engaged in hermeneutic analysis, examining the language used by the participants to talk about their experience, and looking for part/whole relationships. This preliminary analysis helped me to construct the data collection questions for the subsequent interview (i.e., the next conversational interview), and it also played an integral part in shaping my interpretation. After data collection was complete, I engaged in another layer of analysis where I examined all the data for each participant. I began my analysis of each case by constructing a narrative portrait of the participant (Ellis 2006, 2009) and then began to develop themes and new insights from all the data for each case (individual case analysis). I examined the data across cases (cross-case analysis), comparing and contrasting the experience of the participants, looking for larger themes, and going back and forth between my preliminary analysis of each participant, and the literature and my theoretical framework.

\section{Through the Lens of Dewey's Theory of Experience: Reflections and Insights}

As I reflect on writing this article, it occurs to me that the very act of doing so constitutes yet another layer of analysis related to the impact of Dewey's theory on my analysis. While working with Dewey's theory of experience helped me to think in a specific way, I was not specifically looking for continuity, situation, interaction, or other Deweyan concepts during analysis. As Merriam (1998) reminds me, the purpose of qualitative case study is discovery, not confirmation. In other words, while my starting assumption was that teachers learn from their experience, I was not trying to confirm that the process of professional learning 'fits' with Dewey's criteria for experience. Instead, I used Dewey's theory as an analytical tool, which helped me to think hermeneutically and facilitated part/whole analysis in a number of ways. In the following section, I provide an example of how each of the above-mentioned concepts from Dewey's theory (i.e. continuity, interaction, and situation) were useful in analyzing the data related to the participants' experience as teachers and professional learners. In the final section of this essay, I offer some reflections on the limitations of the theory of experience as an analytical framework and suggest two other theoretical tools to supplement a Deweyan perspective of teacher learning.

Jody Stark. 2020. Dewey's theory of experience: A theoretical tool for researching music teacher learning. Action, Criticism, and Theory for Music Education 19 (1): 118-52. https://doi.org/ 10.22176/act19.1.118 
Continuity as a Tool for Analysis: Holly's Professional Learning as a Negotiation of Voice

Thinking through the lens of continuity helped me to notice some of the ways in which the participants' biographies impacted their teaching practice and current experience. As I constructed a narrative portrait of each participant and engaged in hermeneutic part/whole analysis, I began to have a sense of continuity related to the experience of each individual as a musical person, teacher, and professional learner. In other words, I began to see specific ways that the participants' biographies informed their teaching and learning. Being sensitized to the idea of continuity led me to a significant insight related to Holly's teaching and learning. In our first interview, Holly spoke at length about her musical life as a young person. While Holly shared some of the music that had been important to her over her life in our first interview, she talked about her family of origin and the expectations of her family and community that she perform. She shared that she did not see herself as a musician growing up:

I knew I loved [music], and I knew I had a passion ... but it wasn't something that I personally- I didn't personally make the music ... I listened to the music. I listened to my tapes and CDs, and I went to tons and tons of concerts. So I was always an audience member.

Holly's dad was a gospel singer and she knew that she did not want to perform like he did, and she knew that she did not want to sing at church or perform in the town-wide piano recital. However, in the telling, Holly discovered that becoming a music teacher had allowed her to be a musician on her own terms rather than those of her family or her community. Looking through the lens of continuity of experience, I began to see Holly's story as a quest for musical voice beginning when she was a young child.

Voice is a concept I take from Belenky, Clinchy, Goldberger, and Tarule (1997) and also from Britzman (2003). While identity is the imagined role that people project of themselves, Britzman frames voice as a metaphor for "the individual's struggle to create and fashion meaning, assert standpoints, and negotiate with others" (34). It involves that aspect of the self that is implicated in negotiating one's participation in the social world (Britzman 2003). Holly's insight about the significance of teaching music for her sense of self helped me to see her professional journey as being rooted in a personal one of finding and negotiating her voice as a

Jody Stark. 2020. Dewey's theory of experience: A theoretical tool for researching music teacher learning. Action, Criticism, and Theory for Music Education 19 (1): 118-52. https://doi.org/ 10.22176/act19.1.118 
teacher, and of becoming empowered as a musical person. This insight became significant when I began to examine Holly's experiences of professional learning. As I analyzed the transcripts from Holly's interviews, I began to theorize that when Holly attended workshops and other professional learning events, she was not just looking for repertoire or activities to use in her music class, she was negotiating her voice in relation to the communities of practice where she found herself, just as she had done while negotiating her musical identity and voice in relation to her family and community when she was growing up. Conceiving of Holly's professional learning as a negotiation of voice helped me to attend to the social and interactive nature of professional learning, another significant theme related to music teacher education and professional learning that informed my interpretation during cross-case analysis. This is just one example of many ways that the concept of continuity was helpful to my analysis. I will now provide an example related to Dewey's concept of interaction.

\section{Interaction and Theorizing Deborah's Professional Learning}

Dewey's (1938/1997) assertion that learning is transactional and results from interaction helped me to notice the many ways that the participants interacted with others in the communities where they were located and how those interactions impacted their learning. One example concerns Deborah's collaborative learning with a colleague.

First, an important note about Deborah. What became salient during analysis of Deborah's experience as a teacher and learner was that Deborah was exceptionally growth-oriented. For example, in a timeline that Deborah made in response to the Pre-Interview Activity prompt "Make a timeline that shows key events or experiences that changed the ways that you have experienced working with music," Deborah framed almost every event she chose to share as part of her story as something that she had learned about teaching, music, or herself. As she finished walking me through her timeline, she pointed to the right side of the page where the timeline ended, and commented, "And then ... now here I cut the timeline off but it really should keep going." That statement proved to be significant in making sense of Deborah's experience as a teacher and as a professional learner.

Jody Stark. 2020. Dewey's theory of experience: A theoretical tool for researching music teacher learning. Action, Criticism, and Theory for Music Education 19 (1): 118-52. https://doi.org/ 10.22176/act19.1.118 


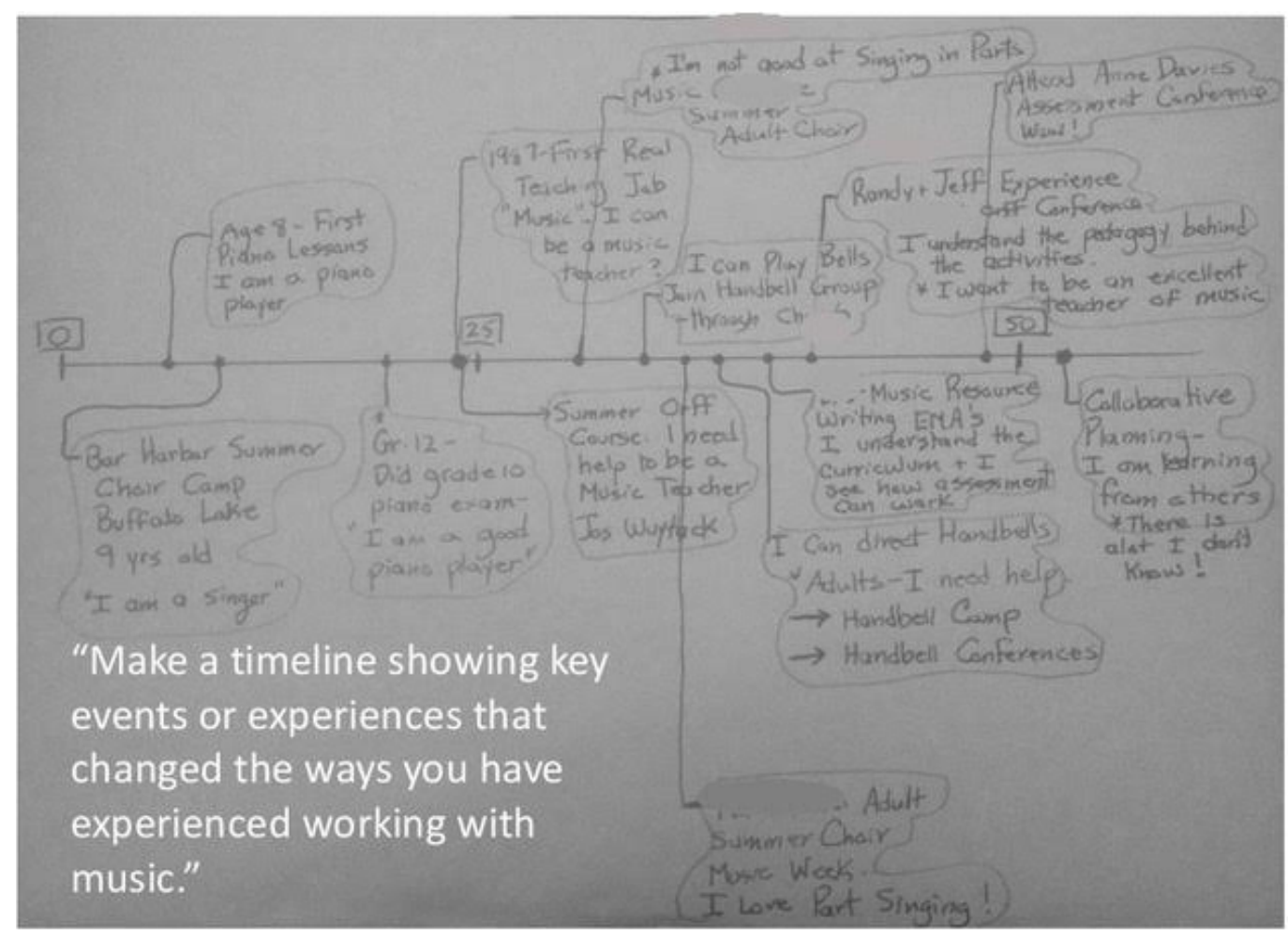

Figure 1: Deborah's PIA timeline response

Deborah's growth orientation was not only evident in her own journey as a teacher, but it was significant in how she approached teaching elementary music students. The "framework for personal judgment" (Polanyi 1962/2005, 32) that seemed to govern Deborah's teaching practice was some version of "helping students to grow in their understanding of curricular concepts." Even the posters on her music room walls, which were summaries of the key learning areas of the curriculum expressed in student-friendly language, were tools that Deborah used to support student learning rather than mere decorations. Given her focus on learning in general and on student learning in particular, it was no surprise that Deborah was keenly interested in assessing what her students knew and could do in relation to the learning outcomes of the provincial music curriculum. Deborah's interest in assessment led her to a collaborative learning arrangement with a colleague.

At the time of the study, Deborah was working on an assessment plan with "Jennifer," who taught music at another school. The two teachers had convinced their principals to pay for a substitute to cover their classes so they could meet once a term for a half day. They also often met after school for coffee, exchanged e-mails, 
and texted each other, sometimes several times a day. Together, Deborah and Jennifer worked to determine which learning outcomes from the provincial curriculum mattered for each grade, how students could demonstrate their understanding of each outcome, and what an exemplar of student work that was "excellent," "needs support," or "needs lots of support" would look or sound like. Deborah and Jennifer's collaboration was ongoing; they had been meeting regularly over a period of two school years at the time of the study, and their collaboration has since continued. Working on this project with Jennifer deepened Deborah's understanding of assessment, learning, and the music curriculum, and led to changes in her practice. Together, Deborah and Jennifer experimented with using an iPad application for assessment, video recording performances using an iPhone microphone and an iPad, and having students record their recorder performances independently using iPad memos. Once Deborah and Jennifer decided what and how they were going to assess, each of them set to work in their classroom working through how to best enact the plan and gather student work. As they did this, they were in regular communication, sharing files and thoughts back and forth often daily or several times a day via cell phone, e-mail, or text message. They also met regularly for coffee, as mentioned above.

Part of the reason Deborah and Jennifer's work was so fruitful is that they frequently checked in with each other as they were learning. They constantly used each other as sounding boards and "someone to think with" when they were evaluating performance examples, often sharing videos or recordings and discussing how they would evaluate a given performance. Deborah explained:

So we've been e-mailing back and forth. She sent me an audio clip of a kid singing and said, "How would you mark this?" And I'm going to send her my audio clip of my recorder player and say, "How would you mark this?" So, you know, just curious. And what it's doing is forcing us to look at the criteria and what's really important when we're evaluating.

The immediacy of their relationship allowed Deborah to move her thinking forward on a continual basis and helped her stay in a state of inquiry. Deborah found the back-and-forth nature of their relationship to be both stimulating and fulfilling, and these aspects of their relationship seemed to result in significant professional learning. Deborah and Jennifer served as mediators for one another's learning (Bodrova and Leong 2007), building shared structures for thinking about assessment and the assessment tools they then helped each other to learn to use.

Jody Stark. 2020. Dewey's theory of experience: A theoretical tool for researching music teacher learning. Action, Criticism, and Theory for Music Education 19 (1): 118-52. https://doi.org/ 10.22176/act19.1.118 
Their transactional relationship allowed them to co-construct their understanding about teaching, music learning, the curriculum, and assessment.

\section{The Impact of Gabriel's Situation on His Professional Learning}

The final element from Dewey's theory of experience that informed my research is that of situation, and I will provide an example of how it served as a useful concept for analysis related to the case of Gabriel.

Attending to the situation of all the participants during analysis was helpful in understanding their experience of teaching and their stance towards professional learning. While Deborah had negotiated a safe space to grow within her school community, Gabriel was a first-year teacher under a lot of pressure to prove himself. Becoming an elementary music teacher was a natural result of Gabriel's situation growing up. Gabriel's aunt and mother had been elementary music teachers. In fact, Gabriel had come from a family of teachers. Both of his parents, his grandmother, and his aunt had been public-school teachers, and he had also recently married a teacher. Gabriel was very aware of the lifestyle benefits and security of teaching in the Canadian public-school system as compared to being a professional musician. ${ }^{4}$ He knew that teachers made a comfortable living, and he had many fond memories of the extended summer holidays his family shared during their summers off. He noted that while he loved playing cello and teaching group and private lessons, he wanted to teach school music because, "I think it comes down also to an economic standpoint. How can I have stability in my life and still do music."

In addition to being aware of the lifestyle benefits of being a public-school music teacher, Gabriel was also aware of the precarity of his situation as a first-year teacher on a probationary contract. In fact, a central theme related to Gabriel's situation was that of survival. Gabriel started the year with a part-time contract, teaching four and a half days a week, although he was given full-time hours later in the year. On the side, Gabriel was also teaching group and private cello lessons four nights a week and on Saturday mornings. My impression was that, although he really enjoyed teaching strings, Gabriel had mostly kept his foot in the door just in case teaching school music didn't work out for next year. Gabriel often expressed his belief that there were few school music teaching positions available in the field,

Jody Stark. 2020. Dewey's theory of experience: A theoretical tool for researching music teacher learning. Action, Criticism, and Theory for Music Education 19 (1): 118-52. https://doi.org/ 10.22176/act19.1.118 
and he intimated that he didn't know if he was going to be asked back to his school the following year.

It is well substantiated that novice teachers tend to experience teaching as something to be survived (Ballantyne 2007, Berg and Miksza 2010, Blair 2008, Fuller 1969, Fuller and Bown 1975, Peterson 2005). Gabriel was no exception. He mentioned several times over the course of the study that his goal was to survive the year. However, attending to the element of situation during analysis helped me to understand what survival meant to Gabriel, and what exactly it was that he was surviving.

Not only was Gabriel feeling unsure of his teaching, which is what I initially thought he meant when he talked about survival, he did not really have the space or time to reflect on his practice to any significant degree. He sometimes genuinely did not know if things were going well, and frequently did not seem to have clarity about what element of his practice he might focus on in order to improve. While Gabriel was aware he was growing, and he experienced first year teaching as "learning so much," he could not step out of the day-to-dayness 5 of his experience to make sense of what he was learning or even to set meaningful goals for his practice or his students' learning. The continuity of Gabriel's experience was overtaken by the present to such a large degree that he had limited access to the past in terms of reflection, or to the future in terms of planning and direction. I came to see Gabriel's experience of first year teaching as one of being almost completely tied up with the present and the very real concerns of each day. This was part of what it meant to survive first-year teaching for Gabriel.

As I analyzed the data for Gabriel's case through the lens of situation, I also began to see that Gabriel's ability to grow was significantly diminished by his preoccupation with future job security and a general feeling he had of being in limbo related to his future career. While it was true that Gabriel experienced first-year teaching as something to be survived due to his lack of experience and inability to reflect, it turned out that Gabriel's feeling of insecurity about the future was a big part of what he meant when he said he was surviving his first year.

Gabriel believed that, in order to have a position the following year, his work "has to be top, top notch to stick around. If you're not doing everything you can, it gets noticed and there's another person waiting for your position." He also commented that he felt the pressure to go "over and beyond" in order to prove himself

Jody Stark. 2020. Dewey's theory of experience: A theoretical tool for researching music teacher learning. Action, Criticism, and Theory for Music Education 19 (1): 118-52. https://doi.org/ 10.22176/act19.1.118 
to his administrators and colleagues. As a result, Gabriel volunteered for several committees and projects in his school. (For example, one day, he cut our meeting short because he had to go mow the grass in the school garden.) However, at the same time, he was sure not to invest too much in case he didn't get to return to his school the following year. As we chatted about his work with the school choir, for example, Gabriel noted that he was not making any plans beyond what the teacher before him had done because he didn't yet know if he would be back the following year. This was also true when it came to setting goals for his practice. Gabriel intimated that he was not really thinking ahead to the next year and what he wanted to work on because "I don't know where I might be in the fall, so ..." Gabriel was preoccupied with his very real and immediate need for security; he did not know what the next year held and whether it was safe to put down roots and invest in this school community. His experience of survival was thus characterized by his felt tension between not investing too much privately and needing to exceed expectations publicly.

In sum, the concepts of situation, interaction, and continuity were useful tools for analysis in that they helped me to notice and develop a deeper understanding of several features of the participants' professional learning. In the following section, I will reflect on the limitations of a Deweyan framework related to studying teacher learning.

\section{Reflections on the Limitations of Dewey's Theory of Experience}

In the preceding section, I offered three examples of how the theory of experience was useful for making sense of the participants' experience of teaching and professional learning. While I found Dewey's theory to be robust in many ways, as I have detailed above, I am mindful that, like all theories, it is more useful for some things than for others; Dewey's theory provided a particular frame which highlighted certain aspects of teacher learning and experience while not highlighting others. In particular, Dewey helped me to notice the impact of the participants' biographies and situations on their teaching and professional learning, and helped me to attend to the ways that their professional growth was impacted by interaction with others. However, there were social and discursive aspects of the participants' learning and experience which Dewey's theory did not adequately support in my interpretive

Jody Stark. 2020. Dewey's theory of experience: A theoretical tool for researching music teacher learning. Action, Criticism, and Theory for Music Education 19 (1): 118-52. https://doi.org/ 10.22176/act19.1.118 
work. In the final section of this article, I discuss how two additional frames that I used to interpret my data, namely Lave and Wenger's sociocultural theory and Bourdieu's practice theory, enabled me to move beyond certain limitations of Dewey's theory of experience. I share one example of my interpretive work for each research question of the study for which I used Lave and Wenger's and Bourdieu's theories respectively, followed by a brief conclusion.

\section{The Discursive Nature of Learning in a Community of Practice}

I stated above that Dewey's concept of continuity helped me to trace the influence of the participants' personal history on their professional learning and teaching, that interaction enabled me to notice the ways that the participants learned from others, and that his theory of experience also helped me to notice the impact of the participants' situation on their learning. While extremely useful in all of these ways, Dewey's theory of experience was less helpful in theorizing the ways that the participants' learning was affected by the discourse of the specific communities of practice in which they were situated. As I engaged in data analysis for my study, I began to notice that Gabriel, Holly, and Deborah didn't just learn in interaction with others; instead, their learning, and what they deemed important to learn, was influenced by the discourses of specific communities of practice. For Gabriel, this was primarily the Orff-Schulwerk community which he had encountered through his mom and aunt who were both Orff-inspired music teachers, the instructors of Orff-Schulwerk levels 1 and 2, the authors of the commercial curriculum he used as the basis of his planning, and members of the local Orff association who put on workshops in the community. Much of Gabriel's professional learning throughout the study related to moving from a general understanding of what Orff-Schulwerk meant, which Gabriel articulated as being a holistic approach to music education through which concepts were intertwined, to a deeper understanding of what OrffSchulwerk meant in practice in relation to the curriculum, the commercial resource mentioned above, and his specific teaching situation.

In contrast, Deborah's professional learning was influenced by the values of her school district, who expected every teacher to have an assessment plan regardless of subject, her colleague Jennifer, with whom Deborah was working on an assessment plan as required by the administration of their schools and school division, and an assessment scholar whose books Deborah had read and whose

Jody Stark. 2020. Dewey's theory of experience: A theoretical tool for researching music teacher learning. Action, Criticism, and Theory for Music Education 19 (1): 118-52. https://doi.org/ 10.22176/act19.1.118 
workshops she had attended. The community of practice in which Deborah and Jennifer were situated valued assessment for learning practices. As a result, Deborah and Jennifer were working together to learn how to assess for learning in their teaching. Their project was essentially to master that which the community of practice valued as important knowledge.

Even more interesting to me was Holly, whose primary focus as a teacher and person seemed to lie in constructing and asserting her identity and voice. While Holly tended to position herself at the edge of various communities of practice, her professional learning was still impacted by what was valued by the communities of practice around her. For example, Holly spoke about what she had learned by attending her new school district's mandatory induction program even though she was not a new teacher, just new to the school district. Despite being required to sit through ten hours of workshops designed primarily for new teachers, Holly had this to say about the experience: "It allows me a bit of insight into what's important to [my new school division]." Holly also explained the difference between the discourses of her old school, where she "had to speak the lingo of mastery and parents being involved and nurturing," and her new school division, suggesting that part of her job was "to be up on that and to sort of function within [her school division's] value system." Part of what Holly was learning in the first year in her new position was what this new community of practice deemed important for teachers to know and do.

In seeking to understand how the participants' learning was impacted by the discourse of the communities in which they were located as outlined above, I looked beyond Dewey to Lave and Wenger's sociocultural theory of learning (Lave 1991, Lave and Wenger 1991, Wenger 1998). Lave and Wenger theorize learning as a social and situated act that takes place in specific communities of practice. A community of practice is "[a group] of people who share a concern, a set of problems, or a passion about a topic, and who deepen their knowledge and expertise in this area by interacting on an ongoing basis" (Wenger, McDermott, and Snyder $2002,4)$. Through mutual engagement in a joint enterprise, members of a specific community of practice create and use a shared repertoire of resources for their local practice (Wenger 1998). As the community continually engages in and negotiates their shared practices, the members also construct and reconstruct the meaning of those practices and their identity in relation to the group. In other

Jody Stark. 2020. Dewey's theory of experience: A theoretical tool for researching music teacher learning. Action, Criticism, and Theory for Music Education 19 (1): 118-52. https://doi.org/ 10.22176/act19.1.118 
words, members of the group learn the practices and values of the group through their legitimate peripheral participation (Lave and Wenger 1991).

Hanks (1991) notes that individuals involved in the process of legitimate peripheral participation are "not gaining a discrete body of abstract knowledge which [they] will then transport and reapply in later contexts" (14). Rather, individuals engage in the work of the community, at a level at which they are able, as they are learning in community. Deborah and Gabriel both entered into a process of legitimate peripheral participation, learning the practices that the community in question valued as they engaged in the community. Holly, by contrast, actively worked to remain on the periphery of the communities with whom she intersected. Although she frequently attended professional learning events organized by the local Orff-Schulwerk and Kodály associations and had personal connections with key individuals in each group, Holly chose not to offer her voice to those communities or to adopt their values as her own. Instead, she elected to stay near the edges, quietly measuring her beliefs about teaching, learning, music, and herself against the beliefs of the community, and personally assessing her practice against the practice of the community.

Using the lens of community of practice theory to analyze the discursive nature of Holly's interactions with and in various communities helped me to see something I don't think I would have otherwise noticed; it concerned the kind of learning in which the participants engaged while attending workshops. Workshops have often been criticized for being ineffective in engendering meaningful changes in teachers' practice due to their short time frame and inside-outside epistemology (Garet et al. 2001). However, one of the most interesting hermeneutic discoveries from this research-which became apparent to me thanks, in part, to Lave and Wenger and also to Holly-was that inciting changes in teachers' practice may not actually be how workshops "work." Even though Holly intentionally chose not to seek full membership in the communities of practice where she interacted, her professional learning was still social and discursive in nature, as I have asserted above. In fact, Holly used workshops organized by the local Orff-Schulwerk and Kodály communities primarily as places to affirm her practice. Holly shared:

Sometimes if you leave [a] session with a feeling of affirmation like, "I'm doing a good job," that's also important. Because not always to feel like, "Oh, there's always so much more to do, and I'll never get there." Sometimes it's okay to feel like, "Hey, I'm doing okay."

Jody Stark. 2020. Dewey's theory of experience: A theoretical tool for researching music teacher learning. Action, Criticism, and Theory for Music Education 19 (1): 118-52. https://doi.org/ 10.22176/act19.1.118 
In short, what Lave and Wenger's community of practice theory helped me to see in my data is that workshops are sites where music teachers can affirm and confirm their practice against the values and members of the community of practice. After having this insight, I went back to the data for all three participants and discovered that all of them engaged in confirmatory learning practices. Gabriel was trying to work out what quality repertoire was in an elementary music context by measuring his choices against the repertoire he encountered in his prior workshop and Orff levels 1 and 2 experiences, and Deborah continually confirmed her assessment practices against those of her colleague Jennifer and the assessment scholar she admired (whose workshops she had attended several times). Interestingly, the participants engaged in confirmatory learning practices during the workshop and for months or even years after the event. The extended timeframe from exposure to an idea to its integration into practice, which I take to be the outcome of teachers' professional learning, was a major theme in my findings from cross-case analysis for my study.

Impact of the Socially Constructed Role of a Music Teacher in an Elementary School

As I attended to the ways that various communities of practice influenced the participants' experiences of teaching and professional learning, I began to also notice that the level of agency they experienced was impacted by the power structures in which they worked and learned. According to Mills (1969) and White (2004), pragmatist commitments, including those of Dewey, do not acknowledge the impact of "embedded structural power on a community's [or person's] ability to solve problems" (Stark 2014, 97). While I found this to be the case with Dewey's theory of experience, I would like to point out that it is not necessarily true of all of Dewey's work. For example, Midtgarden (2012) asserts that Dewey "confronts the issue of domination and power on a broad scale" in his historical approach to social philosophy (507). Midtgarden is referring especially to Dewey's Lectures in China, where Dewey critiques what he calls the authority of tradition. However, because I wanted to explore the ways that the participants' practice was influenced by virtue of their being music teachers in public elementary schools, I turned to Bourdieu (1977) and the concepts of field, habitus, and, cultural and social capital. While I

Jody Stark. 2020. Dewey's theory of experience: A theoretical tool for researching music teacher learning. Action, Criticism, and Theory for Music Education 19 (1): 118-52. https://doi.org/ 10.22176/act19.1.118 
used Bourdieu's concepts to interpret my data during cross-case analysis, I confess that my application of Bourdieu was pragmatically selective and fairly non-critical. Rather than theorizing the participants' experience in their schools as a struggle for position within a specific social field (Siisaäinen 2000), I instead used Bourdieu to tease out the structural elements of the participants' experience.

Bourdieu conceives of human experience as taking place in social fields where individuals deploy their economic, social, and cultural capital to define their position within those fields. Social actors' dispositions and possibilities in a field are directed by their habitus (Bourdieu 1977), consisting of "systems of durable, transposable dispositions, structured structures predisposed to function as structuring structures ... without in any way being the product of obedience to rules" (72). As a "product of history" (82), habitus shapes thought and behaviour in specific social worlds, such as one's given social class or profession. Siisiäinen notes that habitus "preconditions the freedom-and voluntary character-of the actor's choices" $(2000,16)$. Related to teaching elementary music, one might say that habitus results in specific individual and collective practices that add up to being an elementary music teacher.

Gabriel's experience as a private string student and orchestra member had provided him few models for teaching elementary classroom music. Bourdieu helped me to notice that, even though Gabriel did not have many biographic resources to inform his pedagogy as an elementary music teacher (Britzman 2003), and even though he lacked certain skills due to his inexperience, Gabriel still knew to some degree how to be an elementary music teacher. Part of how he knew what to do was by noticing the expectations of others in his school community. When his colleagues assumed that he would know how to plan and direct the school's winter concert, plan assemblies, or teach folk dancing, Gabriel assumed the role of expert related to these projects. The role of music teacher served as a resource to give Gabriel a certain unquestioned status in the school, even though he was new at the job and didn't necessarily know what to do (Callero 1994). Deborah and Holly also experienced having unquestioned authority by virtue of their positions. I expected to find that the actions of the participants in my study were constrained by the implicit power structures in their schools, and that was true to some degree, but, particularly for Holly and Gabriel, I was surprised to find that the discursive 
structures of the schools afforded them a certain amount of cultural and social capital because of their role as music teachers.

Callero (1994) suggests, "roles can be viewed as making action possible" (229). Being music teachers meant that Gabriel, Holly, and Deborah were de facto leaders in their schools. They played a tacitly defined role in their school buildings, whereby they were expected to do and know certain things by virtue of their implied habitus as music teachers. In matters of planning concerts, setting up sound equipment, and hiring artists in residence, their colleagues deferred to them without question, assuming that they knew what to do. Their colleagues also assumed that, as music teachers, Gabriel, Holly, and Deborah were musicians with a certain amount of cultural and social capital in the arts community. Bourdieu (1986) explains cultural capital as any embodied, objectified, or institutionalized "cultural competence" that can be inherited by living in a specific environment or acquired through education (18). Being a musician is a good example of having a kind of cultural capital. Social capital, in contrast, is "the actual or potential resources" one possesses due to membership in a specific group (21). Bourdieu writes:

The volume of the social capital possessed by a given agent depends on the size of the network of connections that [they] can effectively mobilize and on the volume of the capital (economic, cultural or symbolic) possessed in [their] own right by each of those to whom [they are] connected. (21)

For example, because of my position in a university faculty of music, I have a certain social capital. Several of my colleagues are well-known performers with connections to other well-known performers, and our faculty shares a conductor with the local symphony orchestra. All of these connections give me access to a certain network of individuals, each with a certain amount of cultural (and social) capital in the music community in my city and country.

In the case of the participants in my study, the other teachers, staff members, and administrators assumed that they were musicians with connections to other musicians and the arts community, which they could leverage to provide arts programming and events in the school. While not surprising in the case of Gabriel, who was a string player with a music degree and a member of a string quartet, Deborah and Holly mostly saw themselves as teachers and not musicians.

In spite of this, Deborah took up the mantle of cultural leader in the field where she was located and used the social and cultural capital she was afforded to her

Jody Stark. 2020. Dewey's theory of experience: A theoretical tool for researching music teacher learning. Action, Criticism, and Theory for Music Education 19 (1): 118-52. https://doi.org/ 10.22176/act19.1.118 
students' advantage. She planned multiple events each year including concerts and community arts presentations, and successfully made the case for her school to cover the costs of taking the school choir and handbell choirs to participate in festivals and other events. Holly also used the cultural capital that she was given, leveraging her social situation to intentionally transform the culture in her building and shape the curriculum for the entire school. Holly's practice was to pick a theme for a concert or other school wide event and to "sell" it to her staff along with ways they could incorporate the theme in their teaching in Science, Social Studies, Art, Physical Education, and Language Arts, even going so far as to suggest specific units in Science and writing projects. She also implemented a character education program that she tried to get others to take up at her school. In sum, the role of music teacher constrained and directed the participants' actions within their schools, but it also afforded them a certain unquestioned status there. While Gabriel initially hid behind his social and cultural capital as he worked out the nuts and bolts of being a new music teacher, I discovered later that he had used it to set up a joint concert for his students with a local student orchestra, also arranging to start a cello club at his school (personal communication, October 15, 2015). Thus, playing the role of music teacher provided a vehicle for agency for Gabriel, Holly, and Deborah (Callero 1994). For Holly, this meant that she was given creative control of a project (the Christmas concert) that fulfilled her need for voice as a musician. For Deborah, it meant that she could do things she felt were needed to improve student learning in her music program, including asking for a paid substitute teacher in order that she could meet with a colleague for professional learning or requesting buses to take her students to a festival. For Gabriel, it meant that no one questioned his know-how related to music or teaching music, affording him the chance to work out how to teach without evaluation or judgment.

In sum, Bourdieu helped me to notice the ways my research participants' experience of teaching music was influenced by the fields in which they were located, and their role and habitus in an elementary school. In addition, the concepts of cultural and social capital were useful in making sense of assumptions the participants' school communities made about the participants as music educators and musicians. All three participants were able to use those assumptions to their advantage and to the advantage of their students.

Jody Stark. 2020. Dewey's theory of experience: A theoretical tool for researching music teacher learning. Action, Criticism, and Theory for Music Education 19 (1): 118-52. https://doi.org/ 10.22176/act19.1.118 


\section{Concluding Thoughts}

In this article, I have argued that Dewey's theory of experience is a valuable tool for making sense of music teachers' experiences of teaching and professional learning at the level of the teacher's experience, and I have also suggested two other "tools to think with" that were useful to me in my interpretive work, namely Lave and Wenger's community of practice theory, and Bourdieu's concepts of field, habitus, and cultural and social capital.

While reflecting on my interpretive journey, I am struck by the synergy of these three theoretical perspectives. In broad strokes, Dewey, Lave and Wenger, and Bourdieu all share a sociocultural framing and attempt to explicate the impact that community and environment have on an individual's experience, learning, and possible future. While Dewey focuses on how individuals learn, and the concept of learning is "remarkably undertheorized" for Lave and Wenger (Duguid 2008, 2), both theories emphasize the primacy of the individual's environment/situation in learning. Bourdieu's theory of practice also foregrounds the impact of the individual's social world on their experience, through both his notion of field and in the individual's socially and historically constructed habitus.

Framing my research as seeking to understand music teachers' experiences of teaching and learning provided a powerful construct to notice how and why teachers grow and gave me a new understanding of how to support change in their practice. Studying teachers' experience, I would suggest, provides a basis for engendering change in our field and working toward realizing MayDay Group Action Ideal VII. ${ }^{6}$ While this Action Ideal focuses on understanding the context of music curriculum and education and engaging in discussion "which reframes all musical learning," I argue further that we must also reframe music teachers' learning. Ellis has noted that, "The object of research is to develop insight or new learning that transforms the researcher's understanding such that he or she can think more richly and act more usefully in relation to the problem or question studied" (Ellis 2006, 114). This is indeed the potential of studying music teachers' experiences of teaching and learning.

Jody Stark. 2020. Dewey's theory of experience: A theoretical tool for researching music teacher learning. Action, Criticism, and Theory for Music Education 19 (1): 118-52. https://doi.org/ 10.22176/act19.1.118 


\section{About the Author}

Jody Stark is an assistant professor of music education at the Desautels Faculty of Music at the University of Manitoba in Winnipeg, Canada. In addition to serving as area head for music education, Jody teaches courses on principles and issues in contemporary music education, music pedagogy for early years contexts, and creativity and culture in the music classroom. Jody began her career teaching elementary, choral, and early childhood music in both English and French Immersion programs. Her current research interests include music teacher professional learning, an anti-racist and decolonizing music education, and the learning and teaching of diverse contemporary musical practices.

\section{References}

Allsup, Randall Everett. 2016. Remixing the classroom: Toward an open philosophy of music education. Bloomington, IN: Indiana University Press.

Ballantyne, Julie. 2007. Documenting praxis shock in early-career Australian music teachers: The impact of pre-service teacher education. International Journal of Music Education 25 (3): 181-91. http://doi.org/10.1177/ 0255761407083573

Barrett, Janet. 2006. Recasting professional development for music teachers in an era of reform. Arts Education Policy Review 107 (6): 19-28. http://doi.org/10.3200/AEPR.107.6.19-28

Barrett, Janet. 2009. Graduate music education as a site for reconfiguring curriculum development. Research Studies in Music Education 31 (1): 6-19. https://doi.org/10.1177/1321103X09103625

Bauer, William. 2007. Research on the professional development of experienced music teachers. Journal of Music Teacher Education 17 (1): 12-21.

Bauer, William. 2012. The acquisition of musical technological pedagogical and content knowledge. Journal of Music Teacher Education 22 (2): 51-64.

Bautista, Alfredo, Xenia Yau, and Joanne Wong. 2017. High-quality music teacher professional development: A review of the literature. Music Education Research 19 (4): 455-69. http://doi.org/10.1080/14613808.2016.1249357

Baxter, Pamela, and Susan Jack. 2008. Qualitative case study methodology: Study design and implementation for novice researchers. The Qualitative Report 13 (4): 544-59.

Jody Stark. 2020. Dewey's theory of experience: A theoretical tool for researching music teacher learning. Action, Criticism, and Theory for Music Education 19 (1): 118-52. https://doi.org/ 10.22176/act19.1.118 
Belenky, Mary Field, Blythe McVicker Clinchy, Nancy Rule Goldberger, and Jill Mattuck Tarule. 1997. Women's ways of knowing. New York, NY: Basic Books.

Berg, Margaret. and Peter Miksza. 2010. An investigation of preservice music teacher development and concerns. Journal of Music Teacher Education 20 (1): 39-55. http://doi.org/10.1177/1057083710363237

Blair, Deborah. 2008. Mentoring novice teachers: Developing a community of practice. Research Studies in Music Education 30 (2): 99-117. http://doi.org/10.1177/1321103Xo8097502

Bodrova, Elena, and Deborah Leong. 2007. Tools of the mind: The Vygotskian approach to early childhood education. Upper Saddle River, NJ: Pearson.

Bourdieu, Pierre. 1977. Outline of a theory of practice. New York, NY: Cambridge University Press.

Bourdieu, Pierre. 1986. The forms of capital. In Handbook of theory and research for the sociology of education, edited by John G. Richardson, 241-58. New York, NY: Greenwood Press.

Borko, Hilda. 2004. Professional development and teacher learning: Mapping the terrain. Educational Researcher 33 (8): 3-15.

Bredo, Eric. 1997. The social construction of learning. In Handbook of academic learning: Construction of knowledge, edited by Gary D. Phye, 3-45. San Diego, CA: Academic Press.

Britzman, Deborah. 2003. Practice makes practice. Albany, NY: SUNY Press.

Brodsky, Garry M. 1964. Dewey on experience and nature. The Monist 48 (3): 366281.

Burkett, Eugenie. 2011. A case study of issues concerning professional development for rural instrumental music teachers. Journal of Music Teacher Education 21 (1): 51-64.

Bush, Jeffrey. 2007. Importance of various professional development opportunities and workshop topics as determined by in-service music teachers. Journal of Music Teacher Education 16 (2): 10-18. http://doi.org/10.1177/10570837070160020103

Butler, Abby. 2001. Preservice music teachers' conceptions of teaching effectiveness, microteaching experiences, and teaching performance. Journal 
of Research in Music Education 49 (3): 258-72. http://doi.org/10.2307/ 3345711

Callero, Peter. 1994. From role-playing to role-using: Understanding role as resource. Social Psychology Quarterly 57 (3): 228. http://doi.org/10.2307/ 2786878

Conway, Colleen. 2007. Setting an agenda for professional development policy, practice, and research in music education. Journal of Music Teacher Education 17 (1): 56-61.

Conway, Colleen. 2008. Experienced music teacher perceptions of professional development throughout their careers. Bulletin of the Council for Research in Music Education 176: 7-18.

Conway, Christensen, Stephanie Christensen, Mandi Garlock, Erin Hansen, Jill Reese, and Tavia Zerman. 2012. Experienced music teachers' views on the role of journal writing in the first year of teaching. Research Studies in Music Education 34 (1): 45-60. https://doi.org/10.1177/1321103X12445665

Conway, Colleen, Shannon Hibbard, Dan Albert, and Ryan Hourigan. 2005. Professional development for arts teachers. Arts Education Policy Review 107 (1): 11-14. http://doi.org/10.3200/AEPR.107.1.11-14

Conway, Colleen, John Eros, and Ann Marie Stanley. 2009. Perceived effects of the master of music in music education on P-12 teaching practice. Research Studies inv Music Education 31 (2): 129-41. https://doi.org/10.1177/ 1321103X09344381

de Vries, Siebrich, Ellen Jansen, and Wim van de Grift. 2013. Profiling teachers' continuing professional development and the relation with their beliefs about learning and teaching. Teacher and Teacher Education 33: 78-89.

Dewey, John. 1925/2018. Experience and nature. New York, NY: Dover Publications.

Dewey, John. 1934/1980. Art as experience. New York, NY: Milton, Balch, and Co.

Dewey, John. 1938/1997. Experience and education. New York, NY: Collier Macmillan.

Dorfman, Jay and Scott Lipscomb. 2005. Graduate music students' attitudes towards research. Journal of Music Teacher Education 15: 31-42. 
Doyle, Jennifer. 2012. Music Teacher Perceptions of Issues and Problems in Urban Elementary Schools. Bulletin of the Council for Research in Music Education 194: 31-52. https://doi.org/10.5406/bulcouresmusedu.194.0031

Duguid, Paul. 2008. Community of practice then and now, 1-10. In Community, economic creativity, and organization, edited by Ash Amin and Joanne Roberts New York NY: Oxford University Press.

Ellis, Julia. 2006. Researching children's experience hermeneutically and holistically. The Alberta Journal of Educational Research 52 (3): 111-26.

Ellis, Julia. 2009. Interpreting results. In Encyclopedia of case study research, edited by Albert J. Mills, Gabrielle Durepos, and Elden Wiebe, 484-86. Thousand Oaks, CA: Sage.

Ellis, Julia, Vera Janjic-Watrich, Vicki Macris, and Richelle Marynowski. 2011. Using exploratory interviews to re-frame planned research on classroom issues. Northwest Passage 9 (1): 11-18.

Fuller, Frances. 1969. Concerns of teachers: A developmental conceptualization. American Educational Research Journal 6 (2): 207-26.

Fuller, Frances, and Oliver Bown. 1975. Becoming a teacher. Chicago, IL: National Society for the Study of Education.

Garet, Michael, Andrew Porter, Laura Desimone, Beatrice Birman, and Kwang Yoon. 2001. What makes PD effective? Results from a national sample of teachers. American Educational Research Journal 38: 915-46.

Garrison, Jim. 1994. Realism, Deweyan pragmatism, and educational research. Educational Research 23 (5): 5-14. http://doi.org/10.3102/0013189X02300 1005

Gates, Terry. 1974. A philosophy of music education based on writings of John Dewey. EdD diss., University of Illinois at Urbana-Champaign.

Hanks, William. (1991). Foreword. In Situated learning: Legitimate peripheral participation, edited by Jean Lave and Etienne Wenger, 13-24. Cambridge, England: Cambridge University Press.

Kastner, Julie. 2014. Exploring informal music learning in a professional development community of music teachers. Bulletin of the Council for Research in Music Education 202: 71-89. 
Kos, Ronald, and Andrew Goodrich. 2012. Music teachers' professional growth: Experiences of graduates from an online graduate degree program. Visions of Research in Music Education 22: 1-26.

Lave, Jean. 1991. Situating learning in communities of practice. In Perspectives on socially shared cognition, edited by Lauren B. Resnick, John M. Levine, and Stephanie D. Teasley,17-36. Washington, DC: American Psychological Association.

Lave, Jean, and Etienne Wenger. 1991. Situated learning: Legitimate peripheral participation. New York, NY: Cambridge University Press.

Leonhard, Charles, and Robert House. (1959/1971). Foundations and principles of music education. New York, NY: McGraw Hill.

Merriam, Sheran. 1998. Qualitative research and case study applications in education. San Francisco, CA: Jossey-Bass.

Mills, C. Wright. 1969. Sociology and pragmatism: The higher learning in America. New York, NY: Oxford University Press.

Midtgarden, Torjus. 2012. Critical Pragmatism: Dewey's social philosophy revisited. European Journal of Social Theory 15 (4): 505-21. http://doi.org/10.1177 /1368431011432373

Odena, Oscar, and Graham Welch. 2007. The influence of teachers' backgrounds on their perceptions of musical creativity: A qualitative study with secondary school music teachers. Research Studies in Music Education 28 (1): 71-81. http://doi.org/10.1177/1321103X070280010206

Opfer. Darlene, and David Pedder. 2011. Conceptualizing teacher professional learning. Review of Educational Research 81 (3): 376-407. http://doi.org/ 10.3102/0034654311413609

Oral, Sevket. 2012. John Dewey's concept of consummatory experience and its relevance to teacher education. Elementary Education Online 11 (1): 161-72.

Patterson, Michael, and Daniel Williams. 2002. Collecting and analyzing qualitative data: Hermeneutic principles, methods, and case examples. Champagne, IL: SAGE.

Jody Stark. 2020. Dewey's theory of experience: A theoretical tool for researching music teacher learning. Action, Criticism, and Theory for Music Education 19 (1): 118-52. https://doi.org/ 10.22176/act19.1.118 
Pellegrino, Kristen. 2011. Exploring the benefits of music-making as professional development for music teachers. Arts Education Policy Review 112 (2): 7888.

Peterson, Elizabeth. 2005. Expectations and experiences: Case studies of three first-year instrumental music teachers. Doctoral diss., Shenandoah University. Retrieved from ProQuest Dissertations and Theses database. (UMI No. 3257861)

Poekert, Philip E. 2012. Teacher leadership and professional development: Examining links between two concepts central to school improvement. Professional Development in Education 38 (2): 169-88.

Polanyi, Michael. 1962/2005. Personal knowledge: Towards a post-critical philosophy. London, England: Routledge.

Raschdorf, Taeryn Kae. 2015. Informal mentoring relationships: A multiple case study of novice music educators and their mentors. Doctoral diss., University of Colorado, Boulder.

Regelski, Thomas. 2017. Pragmatism, praxis, and naturalism: The importance for music education of intentionality and consummatory experience in music praxes. Action, Criticism, and Theory for Music Education 16 (2): 102-43. http://doi.org/10.22176/act16.1.102

Reimer, Bennett. 1970/1983/2003. A philosophy of music education: Advancing the vision. Upper Saddle River, NJ: Prentice Hall.

Robbins, Janet, and Patrick Schmidt. 2011. Looking backwards to reach forward: A strategic architecture for professional development in music education. Arts Education Policy Review 112 (2): 95-103. http://doi.org/10.1080/10632913. 2011.546702

Shaw, Julia. 2017. Creating artistry: Pathways to teacher growth in a professional development short course. Bulletin of the Council for Research in Music Education 213: 27-52. https://doi.org/10.5406/bulcouresmusedu.213.0027

Siisiäinen, Martti. 2000. Two concepts of social capital: Bourdieu vs. Putnam. In ISTR Volume II Conference Working Paper Series. Paper presented at the ISTR Fourth International Conference (Ireland), Dublin, July 5-8. Dublin: International Society for Third-Sector Research.

Sindberg, Laura. 2016. Elements of a successful professional learning community for music teachers using comprehensive musicianship through performance.

Jody Stark. 2020. Dewey's theory of experience: A theoretical tool for researching music teacher learning. Action, Criticism, and Theory for Music Education 19 (1): 118-52. https://doi.org/ 10.22176/act19.1.118 
Journal of Research in Music Education 64 (2): 202-19. https://doi.org/10.1177/

0022429416648945

Stanley, Ann Marie. 2009. The experiences of elementary music teachers in a collaborative teacher study group. PhD diss., University of Michigan. Retrieved from ProQuest Dissertations, 3354182.

Stanley, Ann Marie. 2011. Professional development within collaborative teacher study groups: Pitfalls and promises. Arts Education Policy Review 112 (2): 718. http://doi.org/10.1080/10632913.2011.546692

Stanley, Ann Marie. 2012. The experiences of elementary music teachers in a collaborative teacher study group. Bulletin of the Council for Research in Music Education 192: 53-74.

Stanley, Ann Marie., Alden Snell, and Scott Edgar. 2013. Collaboration as effective music professional development: Success stories from the field. Journal of Music Teacher Education 24 (1): 76-88. http://doi.org/10.1177/ 1057083713502731

Stark, Jody. 2014. The potential of Deweyan-inspired action research. Education and Culture 30 (2): 87-101.

Stark, Jody. 2020. Beyond the workshop: An interpretive case study of the professional learning of three elementary music teachers. Research Studies in Music Education. http://doi.org/10.1177/1321103X19871077

Thiessen, Dennis, and Janet Barrett. 2002. Reform-minded music teachers: A more comprehensive image of teaching for music teacher education. In New handbook of research on music teaching and learning, edited by Richard Colwell and Carol Richardson, 759-85. New York, NY: Oxford University Press.

Wells, Muriel. 2013. Elements of effective and sustainable professional learning. Professional Development in Education 40 (3): 488-504. http://doi.org/10. 1080/19415257.2013.838691

Wenger, Etienne. 1998. Communities of practice: Learning, meaning, and identity. Cambridge, England: Cambridge University Press.

Jody Stark. 2020. Dewey's theory of experience: A theoretical tool for researching music teacher learning. Action, Criticism, and Theory for Music Education 19 (1): 118-52. https://doi.org/ 10.22176/act19.1.118 
Wenger, Etienne, Richard McDermott, and William Snyder. 2002. Cultivating communities of practice: A guide to managing knowledge. Boston, MA: Harvard Business School Press.

West, Chad. 2011. Action research as a professional development activity. Arts Education Policy Review 112 (2): 89-94. https://doi.org/10.1080/10632913. 2011.546697

Westerlund, Heidi. 2003. Reconsidering aesthetic experience in praxial music education. Philosophy of Music Education Review 11 (1): 45-62. http://doi.org/ 10.1353/pme.2003.0008

White, Stephen K. 2004. The very idea of a critical social science: A pragmatist turn. In Cambridge companion to critical theory, edited by Fred L. Rush, 310-35. Cambridge: Cambridge University Press.

Williamson, Catherine Paige. 2011. Elementary music educators' perceptions of effectiveness after Orff-Schulwerk training. Doctoral dissertation. Retrieved from ProQuest Dissertations and Theses database. (UMI No. 3459853)

Wojcikiewicz, Steven K. 2010. Dewey, Peirce, and the categories of learning. Education and Culture 26 (2): 65-82.

Woodford, Paul G. 1994. Development of a theory of transfer in musical thinking and learning based on John Dewey's conception of reflective thinking. PhD diss., Northwestern University.

Woodford, Paul G. 2005. Democracy and music education: Liberalism, ethics, and the politics of practice. Bloomington, IN: Indiana University Press.

Woodford, Paul G. 2018. Dewey's bastards: Music, meaning, and politics. In Music and music education in people's lives: An Oxford handbook of music education, edited by Gary E. McPherson and Graham F. Welch, 339-42. New York, NY: Oxford University Press.

Wright, Peter, John McCarthy, and Lisa Meekison. 2005. Making sense of experience. In Funology: From usability to enjoyment, edited by Mark A. Blythe, Kees Overbeeke, Andrew F. Monk, and Peter C. Wright. New York, NY: Kluwer Academic Publishers.

Young, Vanessa. 2013. Professional development and music education. In Debates in music teaching, edited by Chris Philpott and Gary Spruce, 242-58. New York, NY: Routledge. 


\section{Notes}

${ }^{1}$ Dewey is not alone in suggesting a transactional model of human experience. Eisner's (1994) model of how interactions with one's environment result in creating forms of representing one's experience, including communication, music, and art, is also transactional. Many thanks to one of the reviewers of this article who brought this connection to my attention.

${ }^{2} \mathrm{~A}$ Bachelor of Education is the required degree for teacher certification in most of Canada.

3 A Bachelor of Education (After Degree) is a two-year program in a Faculty of Education that results in teacher certification. In order to qualify for admission, students must have completed a bachelor's degree in any field.

4 Music teachers in the province where Gabriel lives earn the same professional salary as teachers of other subjects and have 3 months off per year. They also have outstanding health benefits and are protected by union-negotiated collective agreements.

5 This is actually Holly's term to describe her experience of teaching as a new teacher. She used it to characterize the shift in her thinking from "day-to-dayness" to being able to think about a week, a month, a school term, and even a year as she became more experienced.

${ }^{6}$ See http://www.maydaygroup.org/about-us/action-for-change-in-music-education/ for a detailed description of the MayDay Group's action ideals.

Jody Stark. 2020. Dewey's theory of experience: A theoretical tool for researching music teacher learning. Action, Criticism, and Theory for Music Education 19 (1): 118-52. https://doi.org/ 10.22176/act19.1.118 